PRACE GEOGRAFICZNE

zeszyt $150,2017,7-27$

doi: 10.4467/20833113PG.17.014.7318

Instytut Geografii i Gospodarki Przestrzennej UJ

Wydawnictwo Uniwersytetu Jagiellońskiego

\title{
UDZIAŁ PROCESÓW MROZOWYCH W ROZWOJU BRZEGÓW RZECZNYCH
}

\author{
Karol Augustowski, Jozef Kukulak
}

\section{Contribution of frost processes in the development of river banks}

\begin{abstract}
The aim of this article is to determine the share of frost processes in the annual balance of river bank erosion. Rates of erosional retreat of river banks in Podhale (boundary zone between the Central and Outer Carpathians) were measured for the hydrological year 2013-2014. Bank erosion during the winter half year was caused mainly by frost phenomena (ground ice and needle ice) and during the summer half year - by fluvial processes and mass movements (undercutting, slumping). The share of erosion by fluvial processes in the yearly progress of bank retreat (this amounted to $71 \mathrm{~cm}$ on average) was four times greater than by frost processes, including mass movements. The effects of erosion by frost processes were greatest in the upper parts of banks, built mostly of fine-grained alluvia, while the lower parts, built largely of gravel, were mostly eroded by fluvial processes.
\end{abstract}

Keywords: erosion, river banks, frost phenomena, fluvial processes, West Carpathians

Zarys treści: Celem artykułu jest określenie udziału procesów mrozowych w całorocznym bilansie erozji brzegów rzecznych. Monitorowano za pomocą kołków erozyjnych wielkość erozji aluwialnych brzegów rzek podhalańskich (pogranicze Karpat Centralnych z Zewnętrznymi) w okresie jednego roku hydrologicznego (2013-2014). W półroczu zimowym erozję brzegów powodowały głównie procesy mrozowe (lód gruntowy i włóknisty), w półroczu letnim - procesy fluwialne i ruchy masowe (podcinanie, osuwanie). W rocznym bilansie erozji brzegów (średnio $71 \mathrm{~cm}$ ) udział procesów fluwialnych był 4-krotnie większy niż mrozowych (z udziałem procesów masowych). Większa erozja powierzchni brzegu w wyniku aktywności procesów 
mrozowych w chłodnym półroczu zaznaczyła się w górnych częściach brzegów (zbudowanych z aluwiów drobnoziarnistych), natomiast skutki erozji fluwialnej w półroczu letnim były największe w dolnych partiach brzegów (z aluwiów żwirowych).

Stowa kluczowe: erozja, brzegi rzeczne, procesy mrozowe, procesy fluwialne, Karpaty Zachodnie

\section{Wprowadzenie}

Erozję brzegów rzek powoduje wiele procesów rzeźbotwórczych wzajemnie ze sobą współdziałających (Lawler i in. 1997). Jest to zespół procesów naturalnych i antropogenicznych. Antropogenicznej natury są m.in.: eksploatacja rumowiska rzecznego, budowa zapór wodnych i zagospodarowanie terenów przykorytowych. Szczególnie duże znaczenie odgrywają lokalne zabiegi regulacyjne koryta, które mogą przyspieszać erozję w innych odcinkach brzegów (Neill, Yaremko 1989; Przedwojski 1998). Z procesów naturalnych istotne są: działalność wód płynących i opadowych, ruchy masowe oraz procesy subaeralne (Hooke 1979; Thorne 1982; Lawler 1992, 1995; Lawler i in. 1997, 1999; Couper, Maddock 2001; Banach, Grobelska 2003; Mengoni, Mosselman 2006; Wynn, Mostaghimi 2006; Coffman 2009). Te ostatnie z wymienionych wynikają z cech lokalnego klimatu i zalicza się do nich przede wszystkim osuszanie, uwilgatnianie, zamarzanie i odmarzanie (Wynn i in. 2008). Przyczyniają się one głównie do rozluźnienia materiału w frontalnych częściach brzegów, dlatego są traktowane przez większość badaczy jako procesy „przygotowujące” brzegi do realnej erozji rzecznej lub ruchów masowych (Wolman 1959; Thorne 1990; Van Klaveren, McCool 1998; Green i in. 1999; Couper 2003; Bertrand 2010).

Procesy egzogenne przekształcają brzegi w różnym stopniu. Przedwojski (1998) stwierdza, że „erozja brzegów jest prawdopodobnie najbardziej powszechnym problemem w praktyce inżynierskiej”. Pilarczyk i in. (1989) podkreślają, że istnieją odcinki rzek, na których średnia wielkość cofania się brzegu wynosi ok. $300 \mathrm{~m} \cdot \mathrm{rok}^{-1}$, punktowo dochodząc nawet do $1000 \mathrm{~m} \cdot \mathrm{rok}^{-1}$.

Lawler i in. (1999) odnotował na dziewięciu stanowiskach w brzegach rzek Swale-Ouse (północna Anglia) duże lokalne różnice średniej wielkości erozji w okresie marzec 1996 - maj 1997 - wahały się one od 7,7 cm do 44,0 cm. W tym samym czasie na pobliskiej rzece Ure erozja wynosiła 16,6 cm. Bartley i in. (2006) odnotowali średnią roczną wielkość erozji brzegów rzecznych dla rzeki Daintree o wielkości od $3 \mathrm{~cm}$ do -0,5 cm (odnotowano depozycję osypiska). W Stanach Zjednoczonych Hupp i in. 2009 oszacowali erozję brzegów rzeki Roanoke na 2,4-52 cm, a Coffman (2009) dla potoku Timber (Timber Creek) odnotował wielkość 2,7-15 cm. Merritt i Cooper (2000) określili dla brzegów rzeki Green River maksymalną wielkość erozji na 1,1 m·rok ${ }^{-1}$, Simon i Hupp (1992) na strumieniach w West Tennessee erozję rzędu 0-1,7 $\mathrm{m} \cdot \mathrm{rok}^{-1}$, a Simon i Rinaldi (2000) erozję przekraczającą punktowo 2,1 $\mathrm{m} \cdot \mathrm{rok}^{-1}$. 
Podane wartości erozji oznaczają wielkość cofnięcia się stoku (powierzchni czołowej) badanych brzegów i w takim rozumieniu będą używane również w niniejszym artykule.

Couper i Maddock (2001), opierając się na badaniach erozji brzegów na rzece Arrow w hrabstwie Worcestershire w Anglii, uznali, że procesy subaeralne mogą być bardziej efektywne w rozwoju brzegów, niż do tej pory sądzono, a Yumoto i in. (2006) określili ich udział w wielkości 20-60\%. Couper (2003) odnotował roczną subaeralną wielkość erozji brzegów dochodzącą do 15 cm. Vallejo $(1977,1990)$ i Lawler i in. (1997) stwierdzają, że multigelacja jest jednym z głównych, bezpośrednich rodzajów erozji. Jahn (1961) i Dutkiewicz (1967) podkreślili, że erozja mrozowa oddziałuje intensywniej na klif niż abrazja. Reid (1985) wyliczył na przykładzie jeziora Orwell, że procesy mrozowe stanowią 80-20\% całkowitej erozji tych brzegów, a dla jeziora Sakakawea udział ten wynosi 30-20\% (Reid i in. 1988; Reid 1992). Hill (1973), Thorne, Lewin (1979) oraz Reid (1985), stwierdzili na podstawie badań terenowych, że 90-20\% materiału odspojonego i oderwanego z brzegów rzecznych i jeziornych w okresie zimy i wiosny jest wynikiem działania procesów mrozowych. Teisseyre (1984) uznał erozję mrozową za jeden z głównym czynników warunkujących rozwój brzegów rzecznych, a Lawler (1993) określił udział lodu włóknistego w cofaniu się brzegu na poziomie ok. 43-32\%. Podkreślił jednak, że jest to zależne w głównej mierze od wielkości zlewni. W zlewniach małych za cofanie się brzegów rzecznych odpowiedzialne są procesy subaeralne, w zlewniach średnich - procesy fluwialne, a w zlewniach dużych - ruchy masowe (Lawler 1995). Abernethy i Rutherfurd (1998) na podstawie zaproponowanej hipotetycznej wielkości potencjalnej erozji brzegu podkreślili, że bardziej wyraźna zależność uwypukla się w stosunku do odległości od źródła. Na przykładzie rzeki Latrobe w Australii przedstawili oni, że procesy subaeralne dominują tylko w górnym odcinku dolin rzecznych. W dalszym biegu rzeki znaczenia nabiera erozja fluwialna, by w środkowym odcinku dominującą rolę zaczęły odgrywać procesy masowe.

\section{Cel artykułu}

Zasadniczym celem tego artykułu jest sprawdzenie, jaki udział mają procesy mrozowe (w tym subaeralne) w ogólnym bilansie erozji brzegów rzecznych w okresie jednego roku hydrologicznego. Starano się porównać rozmiary erozji brzegów powodowanej przez procesy mrozowe w półroczu zimowym z ubytkami brzegów powodowanymi działalnością wód płynących (rzeki) i ruchami masowymi. Udziału samych ruchów masowych nie określono jako składnika oddzielnego, dopełniają one bowiem aktywność procesów zarówno mrozowych, jak i fluwialnych, są przeważnie nimi ożywione, ponadto ich efektami na powierzchni brzegów są nie tylko 
formy erozyjne, ale i akumulacyjne. Uzyskane wyniki pomiarów erozji rozpatrzono na tle przebiegu wahań temperatury powietrza przy gruncie w okresie chłodnym i wahań poziomu wody w rzekach w całym roku hydrologicznym. Instalując kołki erozyjne na różnej wysokości brzegów i w osadach aluwialnych o różnym uziarnieniu, starano się ustalić, które strefy brzegów są erodowane intensywniej przez procesy mrozowe, fluwialne lub ruchy masowe.

\section{Obszar i metoda badań}

Badania prowadzono w ciągu jednego roku hydrologicznego (od 1 listopada 2013 do 31 października 2014) na brzegach rzek z przedpola Tatr Polskich. Na tym obszarze (Podhale; 1130-600 m n.p.m.) temperatura powietrza w półroczu zimowym często spada poniżej $0^{\circ} \mathrm{C}$, osiągając wartości minimalne nawet $-37,6^{\circ} \mathrm{C}$ (Rocznik..., 1963). W okresie badanym (2013/2014) ujemne temperatury powietrza notowano w 152 dniach ( 89 dni z mrozem przez całą dobę), a średnia temperatura grudnia 2013 wynosiła $-9,3^{\circ} \mathrm{C}$. Częste wahania temperatury dobowej wokół $0^{\circ} \mathrm{C}$ powodowały cykliczne zamarzanie lub odmarzanie gruntu. Przy długotrwałych i silniejszych mrozach grunt może zamarzać do głębokości 0,5-0,8 m. Pokrywa śnieżna utrzymuje się zwykle przez 100-110 dni, a zlodzenie rzek - 70-100 dni. W ostatnich latach wartości obu tych elementów wykazują duże wahania, zdarzają się też okresy zaniku pokrywy śnieżnej i zlodzenia rzek. W półroczu letnim jest więcej opadów niż zimą (łącznie 600-1200 mm) i występują wezbrania rzek. W badanym okresie największe wezbranie na Wielkim Rogoźniku było w maju 2014 r., kiedy poziom wody podniósł się o 1,1-2,0 m (ryc. 4) i spowodował duże zmiany w konfiguracji brzegów rzeki. Pozostałe wezbrania w lipcu, wrześniu i październiku 2014 r. były już niewielkie (o 0,4-0,5 m) i nie zaznaczyły się erozją brzegów. Spadek podłużny Wielkiego Rogoźnika na odcinku badanych brzegów jest mały (4,8-7,2\%o), koryto jest kręte, z licznymi podcięciami erozyjnymi. Prawie na całej długości koryta brzegi są czołami teras aluwialnych (lokalnie skalno-aluwialnych) o wysokościach 1,5-2 m i 2,5-4 m. Wzdłuż Wielkiego Rogoźnika i jego dopływów założono 5 stanowisk badawczych (ryc. 1), na których zamontowano łącznie 376 kołków erozyjnych (stanowisko 1 - 78 kołków erozyjnych; stanowisko 2 - 113; stanowisko 3 - 30; stanowisko 4 - 87; stanowisko 5 - 68). Różnice w ilości montowanych kołków są adekwatne do długości czynnych brzegów lub przestrzennego zróżnicowania litologii i ułożenia osadów w odsłonięciach. Wybrano stanowiska badawcze na czołach erozyjnie podciętych teras rzecznych (o wysokości 1,8-3,1 m), z odsłoniętą i różną pod względem uziarnienia ich budową wewnętrzną, w bezpośrednim kontakcie z rzeką podczas średnich stanów wody oraz różną ekspozycją względem stron świata. W środkowym biegu Wielkiego Rogoźnika czynne brzegi są krótkie i łukowe, w dodatku mają 


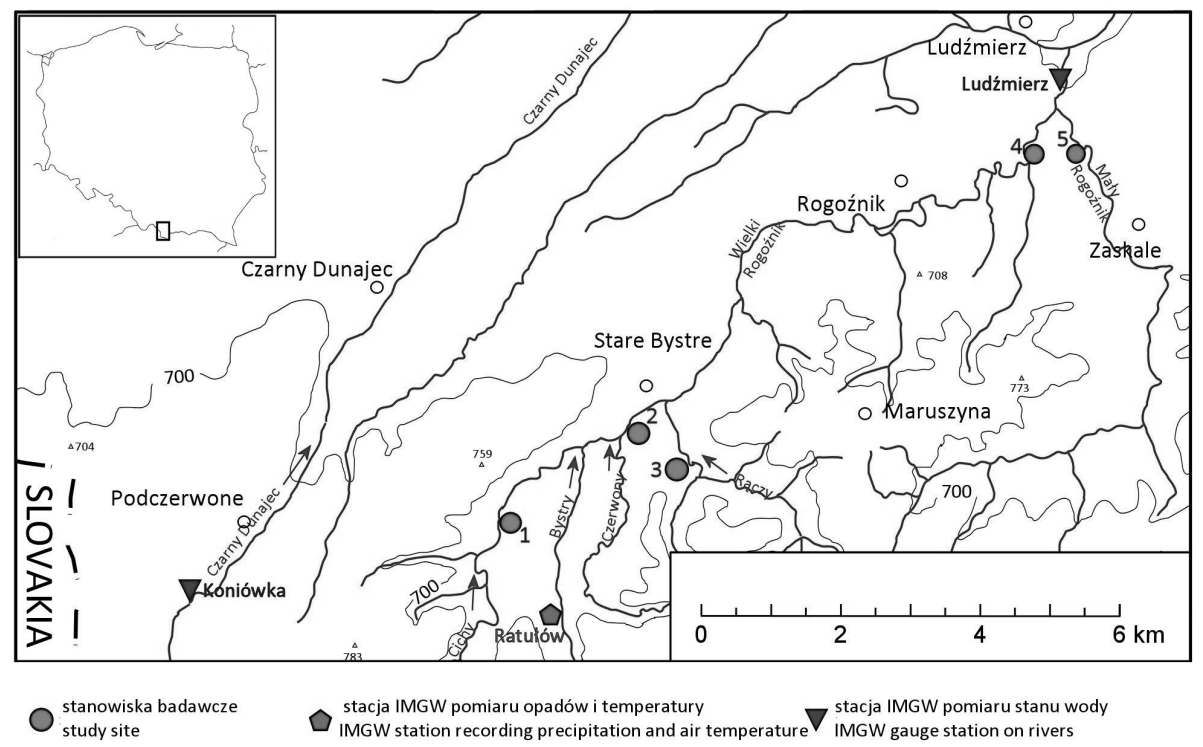

Ryc. 1. Rozmieszczenie stanowisk badawczych i punktów pomiarowych

Fig. 1. Location of study sites as well as hydrological and meteorological stations

podobną budowę geologiczną do badanych, dlatego nie założono tam stanowisk badawczych.

Zastosowana do badania erozji brzegów metoda kołków erozyjnych jest powszechnie stosowana na całym świecie. W Australii tą metodą badano tempo cofania się brzegów rzeki Ngaradj (Saynor i in. 2003), brzegi rzeki Daintree (Bartley i in. 2006) i potoku Gowrie (Howard i in. 1998). We Włoszech wykorzystano ją do badań erozji brzegów rzeki Cecina (Luppi i in. 2008), w Danii - brzegów Odense (Kronvang i in. 2012), w Anglii - brzegów Swale, Ouse i Ure (Lawler i in. 1999), podobnie jak brzegów jeziora Michigan w USA (Vallejo 1977, 1990). Pręty pomiarowe stosowano również do badania tempa erozji i denudacji stoków. Sirvent i in. (1997) wykorzystywali je w północno-wschodniej Hiszpanii, Shi i in. (2011) - w okolicy prowincji Hubei i miasta Chongqing w Chinach, a Arensowi i in. (2004) posłużyły do określenia tempa rozwoju wydm w Kennemerland w Holandii.

Do badań wykorzystano kołki erozyjne (metalowe pręty) o długości 1 m i średnicy $6 \mathrm{~mm}$. Kołek w odległości $20 \mathrm{~cm}$ od jednego z końców oklejono wąską taśmą i drugim końcem wbijano poziomo w stok brzegu na głębokość $80 \mathrm{~cm}$ (po naklejoną taśmę). Odległość odsłony (lub zasłony) kołka poza taśmę była wielkością (mierzoną w mm) 
cofnięcia się powierzchni brzegu po każdym okresie multigelacji (Augustowski 2012, 2013; Augustowski i in., 2012, 2013). Przyjęto głębokość wbijania kołków na $80 \mathrm{~cm}$, ponieważ przemarzanie gruntu w tym regionie, zarówno poziome (od czoła brzegu), jak i pionowe (od góry brzegu) nie przekracza zwykle tej wartości. Każdorazowo po wykonaniu pomiarów, gdy długość wystającego pręta była większa niż $20 \mathrm{~cm}$, były one dobijane do pozycji początkowej. W badanym okresie monitorowano także wahania temperatury powietrza na pobliskim stanowisku pomiarowym w Ratułowie (ryc. 2) i wysokości stanów wody Wielkiego Rogoźnika na stanowisku wodowskazowym Ludźmierz (ryc. 3). Odczyty z prętów prowadzono w okresach multigelacji i zaraz po ich zakończeniu oraz po każdym wezbraniu. W półroczu zimowym roku hydrologicznego 2013/2014 odnotowano dwa okresy multigelacji (ryc. 2). Były to 21 grudnia 2013 - 21 stycznia 2014 oraz 31 stycznia - 15 marca 2014. W okresie jesienno-zimowym pomiary prowadzono 15 grudnia 2013, 10 stycznia 2014, 25 stycznia 2014, 3 marca 2014, 26 marca 2014 i 10 maja 2014. W okresie wiosenno-jesiennym wykonano pomiary w dniach: 24 maja 2014 (po wezbraniu z okresu 14-21 maja) (ryc. 3), 25 lipca 2014 (po wezbraniu z okresu 2-24 lipca), 3 września 2014 oraz 29 października 2014 r. Każdorazowe wyniki pomiarów erozji dla każdego ze stanowisk zestawiono w tabelach i porównano na wykresach.

\section{Stanowisko 1}

Stanowisko 1 obejmuje fragment prawego brzegu potoku Ciche w Miętustwie. Brzeg ma tam 1,8 m wysokości, jest pionowy, świeżo podcięty i eksponowany na zachód. Na tym stanowisku założono dwa poligony badawcze (poligon A i poligon B). $\mathrm{Na}$ pierwszym z nich (poligon A) brzeg jest zbudowany w dolnej części z silnie skonsolidowanych żwirów z piaskiem $(60 \mathrm{~cm})$, wyżej zalegają osady gliniaste, słabo spoiste (ryc. 4a). W obrębie żwirów i glin zamontowano w trzech poziomych rzędach 42 kołki erozyjne. Najniższy rząd kołków wbito w warstwę żwirowo-piaszczystą na wysokości $50 \mathrm{~cm}$ nad lustrem wody (przy niskim poziomie stanów wody). Drugi rząd kołków założono w osadach gliniastych $50 \mathrm{~cm}$ powyżej pierwszego, a trzeci $40 \mathrm{~cm}$ ponad rzędem drugim. Na długości 11,5 m długości brzegu umiejscowiono 14 kolumn kołków erozyjnych.

W odległości $40 \mathrm{~m}$ w górę biegu rzeki założono drugi z poligonów badawczych (poligon B) (ryc. 4b). Warstwa silnie scementowanych żwirów osiąga tam $1 \mathrm{~m}$ ponad lustro wody. W obrębie tej warstwy założono dwa rzędy kołków erozyjnych. $\mathrm{Na}$ żwirach zalegają osady gliniaste $(1,0 \mathrm{~m})$, w które wbito 1 rząd kołków. Brzeg w tym miejscu ma przebieg bardziej prostolinijny i większą wysokość (do $2 \mathrm{~m}$ ). Umiejscowiono w nim łącznie 36 kołków erozyjnych w 3 rzędach i 12 kolumnach na 10-metrowym odcinku brzegu. 


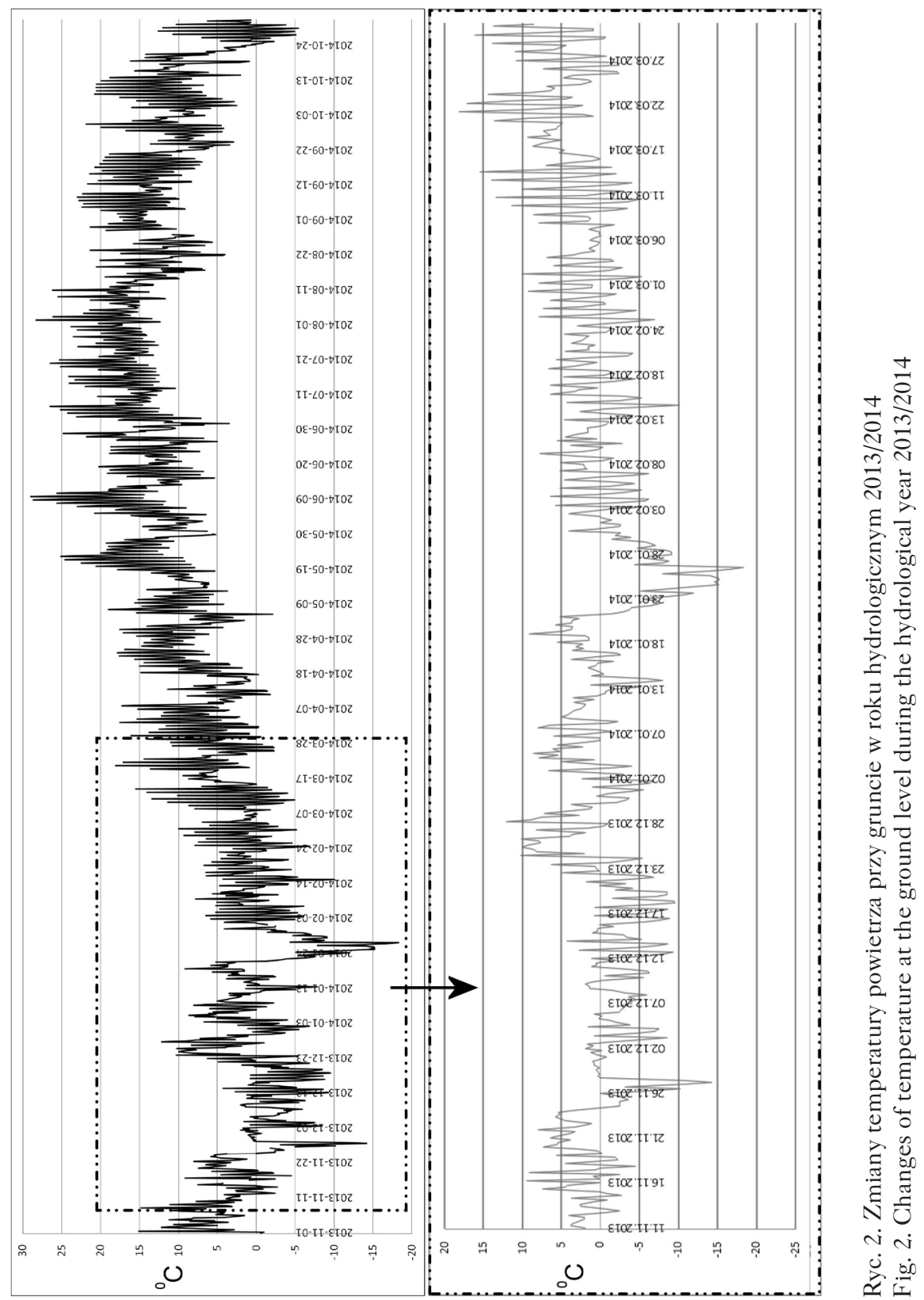



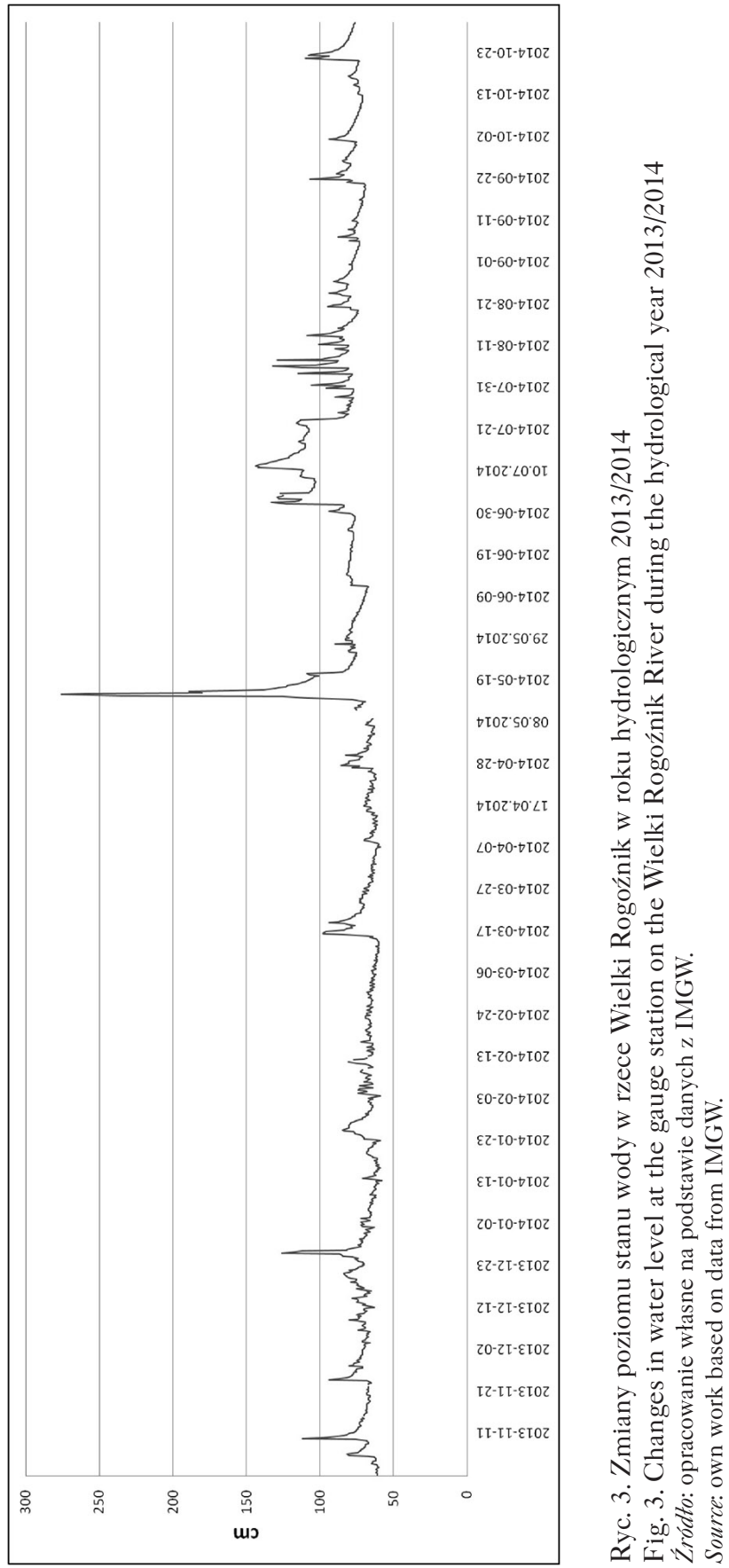

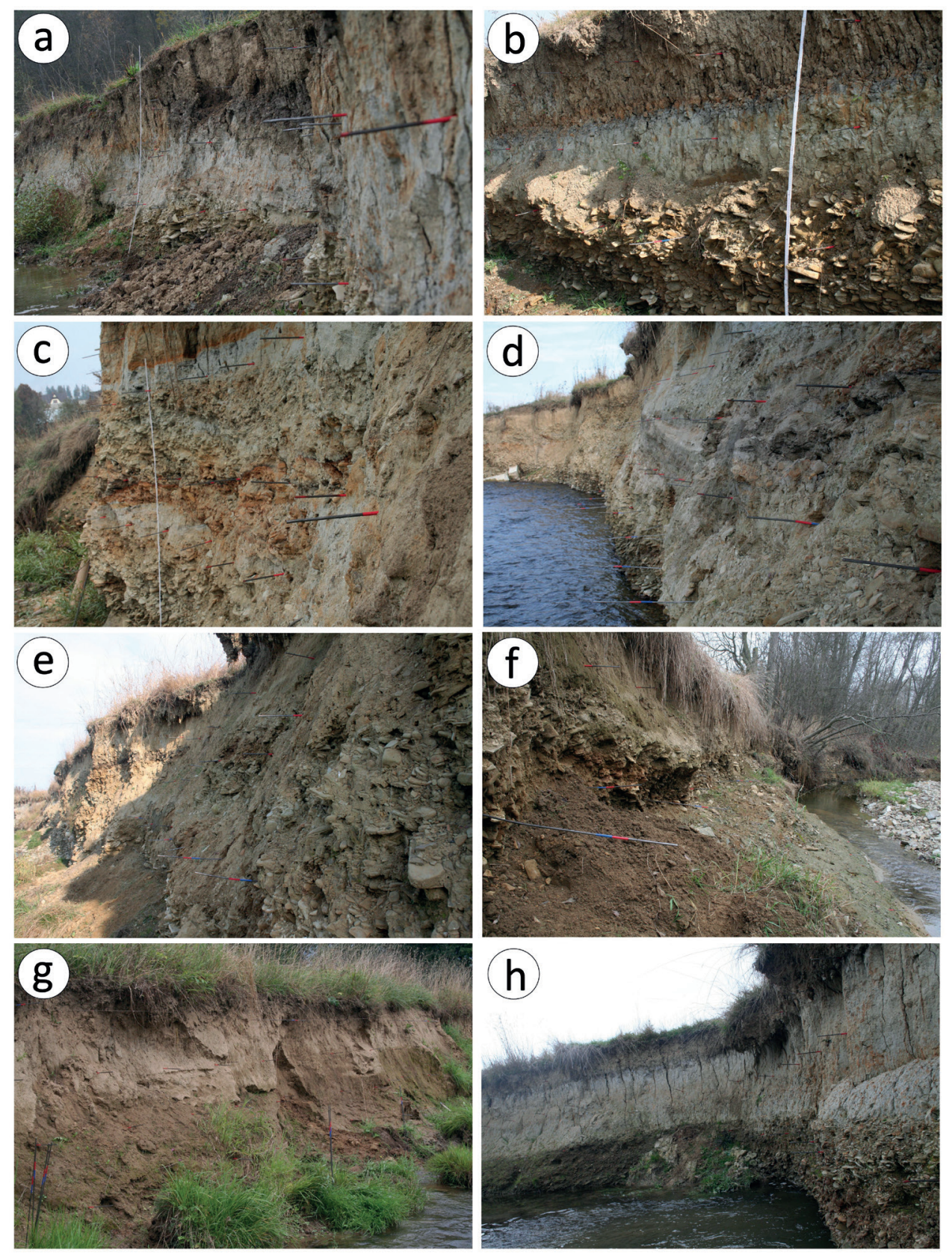

Ryc. 4. Stanowiska pomiarowe

Fig. 4. Study sites

Objaśnienia: stanowisko 1: a) poligon A, b) poligon B; stanowisko 2: c) poligon A, d) poligon B, e) poligon C; f) stanowisko 3; g) stanowisko 4; h) stanowisko 5

Explanations: Site 1: a) plot A, b) plot B; site 2: c) plot A, d) plot B, e) plot C; f) site 3; g) site 4; h) site 5 


\section{Stanowisko 2}

Stanowisko 2 znajduje się na prawym brzegu Wielkiego Rogoźnika (ryc. 4c), na podcięciu 3-metrowej terasy. Brzeg jest świeżo podcięty, ma pionowy stok i jest eksponowany na północny zachód. W profilu pionowym tego podcięcia są dwie warstwy aluwiów. Obie składają się ze średnich i grubych żwirów, a rozdziela je cienki $(0,3 \mathrm{~m})$ poziom piaszczysto-żwirowy z orsztynem oraz rynnowe włożenia laminowanych mułków ze szczątkami drewna (do $1 \mathrm{~m}$ miąższości). Masą wypełniającą w żwirach jest piasek i glina, ale konsolidacja obu warstw jest silna. Nadbudową żwirów jest osad gliniasto-piaszczysty (do $1 \mathrm{~m}$ miąższości), o słabej konsolidacji. W obrębie tego stanowiska założono 3 poligony badawcze w odstępach co $10 \mathrm{~m}$. Pierwszy z poligonów (A) ma długość 5,2 m. W jego obrębie wbito 36 kołków erozyjnych, rozstawionych średnio co $65 \mathrm{~cm}$, w 4 rzędach i 9 kolumnach (ryc. 4c). Brzeg w tym miejscu był osłonięty od wody niską łachą żwirową o szerokości $8 \mathrm{~m}$.

Drugi z poligonów badawczych (B) był omywany wodą przy każdym stanie wody w rzece. Materiał osypiskowy był na bieżąco usuwany z podstawy brzegu (ryc. 4d). Na tym poligonie, o długości $6,5 \mathrm{~m}$, zamontowano 56 kołków erozyjnych rozstawionych co $65 \mathrm{~cm}$ w 4 rzędach i 14 kolumnach (podobnie jak na poligonie A).

Na trzecim z poligonów (C), umiejscowionym dalej w górę rzeki, zamontowano 21 kołków erozyjnych w 3 rzędach i 7 kolumnach (ryc. 4e). Podstawa brzegu na tym odcinku była oddzielona od głównego koryta płytką odnogą rzeki i łachą żwirową o szerokości 3-4 m.

\section{Stanowisko 3}

Umiejscowiono je na lewym brzegu potoku Molczy (prawy dopływ Wielkiego Rogoźnika). Podcięty brzeg ma wysokość 3,0-3,2 m, a jego stok jest eksponowany na wschód. Budowa brzegu na całej długości badanego odsłonięcia jest podobna. W profilu terasy część dolną tworzy 0,5-metrowy cokół z iłów neogeńskich. Na nim zalega 1,5-2-metrowa warstwa bardzo grubych i grubych żwirów z piaskiem, silnie skonsolidowanych. Ich nadbudową $(0,5-1 \mathrm{~m})$ jest warstwa piaszczystej gliny. Profil brzegu jest wklęsły, jego podstawa z iłów jest mniej zerodowana i tworzy wyraźne spłaszczenie (ryc. 4f). Na nim jest deponowany materiał osypiskowy z wyższej części brzegu w okresach między wezbraniami. Materiał ten utrzymuje się na spłaszczeniu do czasu obfitych opadów, kiedy to zostaje spłukany do koryta rzeki. W brzeg wbito 30 kołków erozyjnych rozmieszczonych poziomo w 3 rzędach (po jednym rzędzie w każdej z warstw) i w 10 kolumnach. 


\section{Stanowisko 4}

To stanowisko badawcze założono na prawym brzegu rzeki Wielki Rogoźnik. Jest to brzeg pionowy, podmywany przez rzekę, o wysokości 2,5 m i ekspozycji w kierunku zachodnim. Zbudowany jest w dolnej części z aluwiów piaszczysto-gliniastych (1,8 m), a w górnej - z aluwialnej gliny mułkowo-piaszczystej (0,7 m). Konsolidacja osadów w części dolnej jest słaba, a w części górnej okresowo zmienna, warunkowana termicznie i wilgotnościowo. Większa jest w stanie marzłoci lub letniego wysuszenia, wyraźnie słabsza po opadowym lub roztopowym nawilgoceniu. W obie warstwy aluwiów wbito 87 kołków erozyjnych na odcinku o długości $22 \mathrm{~m}$. Rozstawiono je w 4 rzędach i 22 kolumnach w odległościach między kołkami co $1 \mathrm{~m}$ (w poziomie) i co $0,5 \mathrm{~m}$ (w pionie) (ryc. $4 \mathrm{~g}$ ) Najniższy rząd kołków rozciągał się 0,5 m nad lustrem wody przy jej średnim stanie.

\section{Stanowisko 5}

Stanowisko badawcze założono na lewym brzegu Małego Rogoźnika. Brzeg ma tam 2,2 m wysokości, jego stok jest pionowy, eksponowany na południe. W budowie terasy wyróżniają się 3 warstwy aluwiów (ryc. 4h). Część dolną brzegu tworzy warstwa żwirów średnich (0,7 m miąższości) upakowanych w piasku, słabo skonsolidowanych. Na nich zalega warstwa osadów piaszczysto-gliniastych $(1,1 \mathrm{~m})$, masywnych, gęsto spękanych. Najwyżej znajduje się warstwa osadów gliniastych $(0,4 \mathrm{~m})$, łatwo rozsypliwych. Na pionowej powierzchni brzegu, na odcinku o długości 18,5 m, wbito 68 kołków erozyjnych w 3 rzędach - po jednym rzędzie w każdej z wyróżnionych warstw. Kołki w dolnym rzędzie wbito ok. 0,5 m nad zwierciadłem wody (przy niskim staniewody). W każdym rzędzie instalowano kołki w odległościach co 0,75 m, tworząc w ten sposób 23 ich kolumny (jedynie w kolumnie 14 były 2 rzędy kołków).

\section{Wyniki badań}

Odsłonięcie kołków erozyjnych wskutek cofania się powierzchni brzegów powodowanego przez procesy mrozowe było na badanych stanowiskach zróżnicowane. W okresach multigelacji na poligonie A stanowiska 1 (ryc. 1) brzeg cofnął się o $34 \mathrm{~cm}$ (wartość średnia ze wszystkich kołków poligonu), ale wielkość erozji w poszczególnych rzędach był różna - w rzędzie najwyższym (1,4 m nad lustrem wody) średnia wielkość erozji wyniosła $39 \mathrm{~cm}$, w środkowym $(1,0 \mathrm{~m})$ rzędzie $38 \mathrm{~cm}$, w najniższym $(0,5 \mathrm{~m}) 26 \mathrm{~cm}$ (tab. 1). Podane wyżej wielkości erozji brzegów zostały znacznie przekroczone wiosną podczas największego w całym roku wezbrania rzek (ryc. 3). 
W połowie maja poziom wody w rzece przy stanowisku 1 podniósł się o 1,1 m, erozja boczna rzeki spowodowała wtedy cofnięcie się brzegu o minimum $80 \mathrm{~cm}$, dlatego poligon badawczy A został w całości zniszczony. Na poligonie B stanowiska 1 wielkość erozji powodowanej działaniem procesów mrozowych wyniosła średnio 13,7 cm i była podobna przy kołkach we wszystkich rzędach. W wyniku erozji brzegu przez wezbranie w maju brzeg na poligonie B cofnął się średnio o $45 \mathrm{~cm}$ (w najwyższym rzędzie - o $32 \mathrm{~cm}$, w rzędzie środkowym o $50 \mathrm{~cm}$, w najniższym o $53 \mathrm{~cm}$. Mniejsze wezbrania rzeki w lipcu i wrześniu 2014 r. nie spowodowały już znaczących ubytków brzegów (0,7-3,1 cm) (tab. 1).

Na stanowisku 2 w trakcie majowego wezbrania zostały zniszczone dwa z trzech poligonów badawczych (A i B), brzeg na tych dwóch poligonach cofnął się wtedy o co najmniej $80 \mathrm{~cm}$. W związku z tym, z tego stanowiska, zostały tylko dane dla erozji mrozowej. Przetrwał wezbranie tylko poligon $\mathrm{C}$, na którym erozja rzeczna brzegu była w maju nieco mniejsza $(55-70 \mathrm{~cm})$, a letnio-jesienne wezbrania powiększyły jej rozmiary o dalsze $2-3 \mathrm{~cm}$. Sumarycznie na tym poligonie erozja fluwialna wyniosła prawie $64 \mathrm{~cm}$ (średnia ze wszystkich rzędów). W trakcie tych wezbrań powierzchnia brzegu była silniej erodowana w rzędzie kołków dolnych (do $73 \mathrm{~cm}$ ), zarówno przez płynącą wodę, jak i grawitacyjne obrywy żwirów. Na tym stanowisku (2) pełny zapis mają natomiast skutki procesów mrozowych. O ile na poligonach A i C erozja w okresach multigelacji była niewielka (średnio 10,5-9,5 cm), o tyle na poligonie B procesy mrozowe odegrały znaczącą rolę - średnia wielkość erozji po okresie zimowym i ustaniu wahań temperatury wokół $0^{\circ} \mathrm{C}$ wyniosła aż $40,4 \mathrm{~cm}$, w dodatku była różna w poszczególnych warstwach żwirów. Największe ubytki brzegu stwierdzono w najniższym rzędzie kołków (ok. $60 \mathrm{~cm}$ nad lustrem wody) - średnio $62 \mathrm{~cm}$. W wyższym rzędzie $(1,2 \mathrm{~m})$ brzeg cofnął się o 40,4 cm, a w dwóch najwyższych poziomach kołków (1,8 m, 2,4 m) o ok. $29 \mathrm{~cm}$ (tab. 1, ryc. 5).

Kołki erozyjne na stanowisku 3 przetrwały wiosenno-letnie wezbrania potoku Molczy. Poziom wody nie był tam tak wysoki jak na Wielkim Rogoźniku i dzięki temu zakres zapisu wielkości erozji brzegu jest pełny. Średnia wartość erozji mrozowej wynosiła tam zaledwie $8,2 \mathrm{~cm}$, ale w pionowym profilu brzegu była zróżnicowana. Zimą materiał osypiskowy z silnie erodowanej części górnej brzegu $(31,3 \mathrm{~cm}$ w górnym rzędzie kołków - 2,4 m nad lustrem wody) był deponowany na ilastym spłaszczeniu dolnej części brzegu. Na tym spłaszczeniu kołki erozyjne w rzędzie drugim $(1,6 \mathrm{~m})$ zostały częściowo zasypane zwietrzeliną (stąd ujemne wartości erozji - tab. 1, 2). Sama ilasta część brzegu została w półroczu zimowym zerodowana przez procesy mrozowe o $6,9 \mathrm{~cm}$ (średnia z kołków w rzędzie najniższym - 0,4 m). Wyższe stany wód w półroczu letnim sprzyjały usuwaniu materiału osypiskowego z okresu zimowego i tym samym erozja boczna powodowana przepływem wody sięgała również drugiego rzędu kołków. Skutki tego typu erozji były równe ubytkom brzegu powodowanym przez procesy mrozowe (po $8 \mathrm{~cm}$ ). 


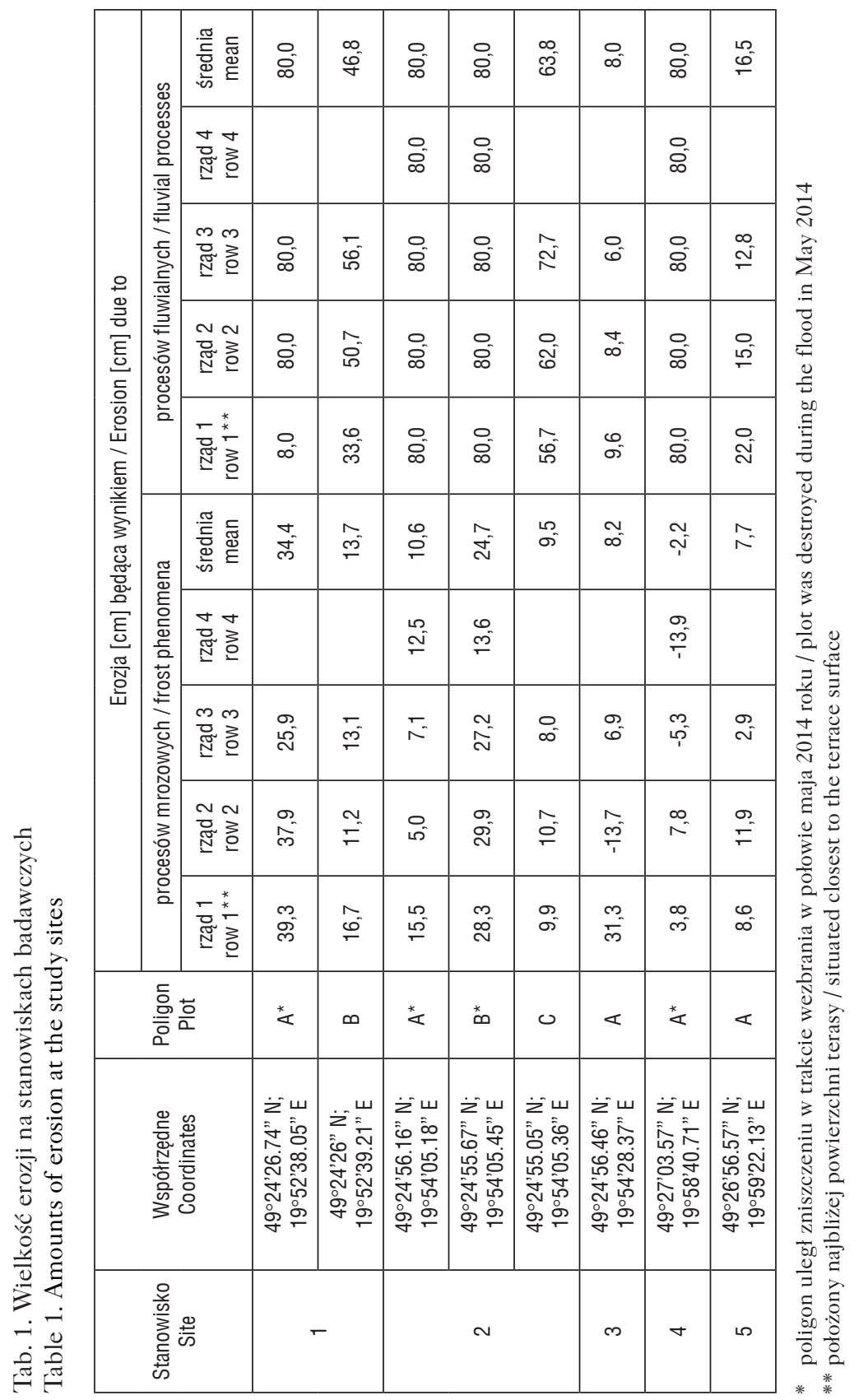



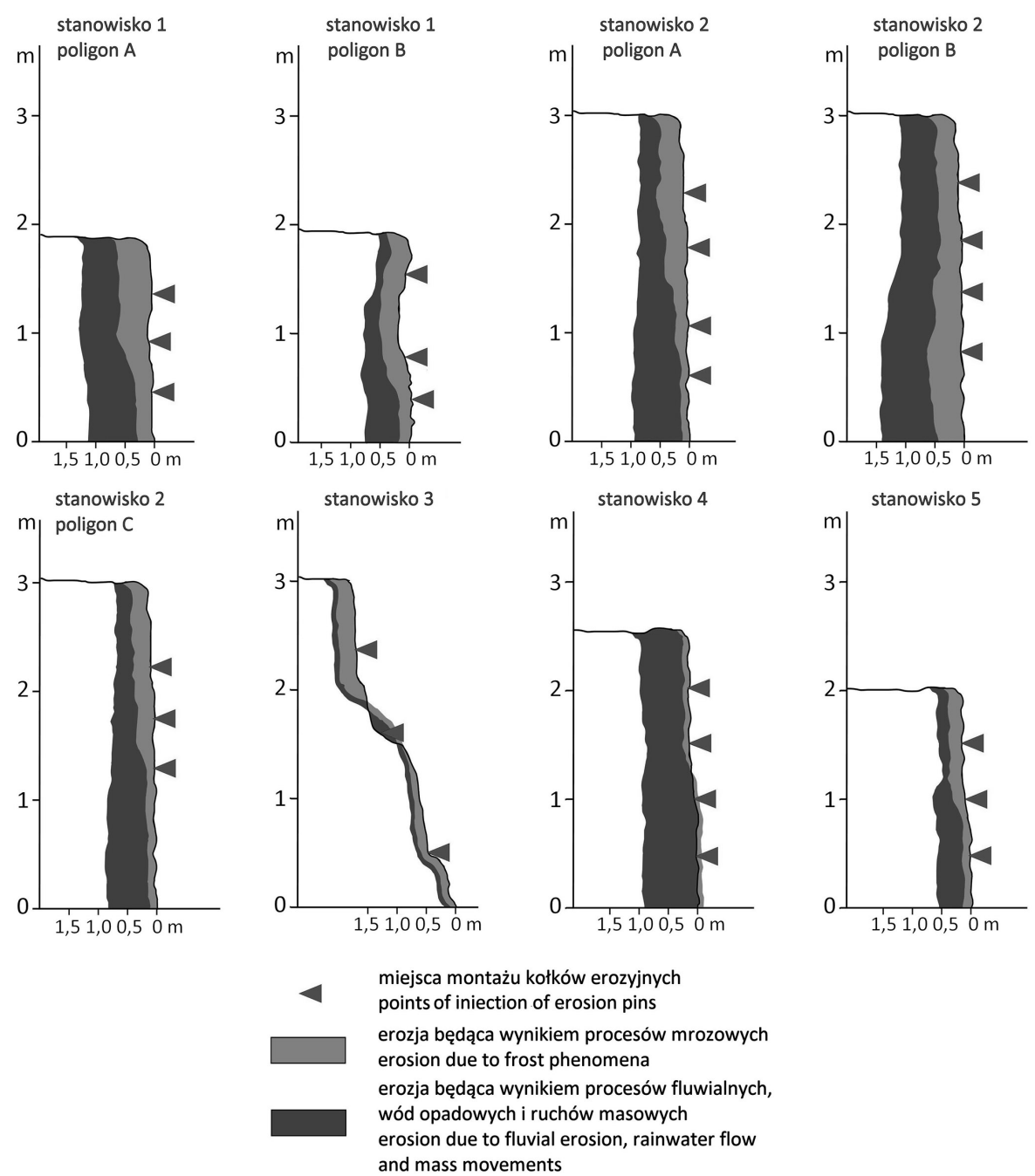

Ryc. 5. Przekształcenia powierzchni brzegu na stanowiskach badawczych Fig. 5. Modifications of river banks at the studied sites

Brzeg na stanowisku 4 został znacząco zmieniony podczas majowego wezbrania, a poligon z kołkami erozyjnymi w całości zniszczony. Zarejestrowano tam jedynie skutki działania procesów mrozowych. W porównaniu z innymi stanowiskami rozmiary mrozowej erozji brzegu okazały się niewielkie. Powierzchnia brzegu w strefie 
Tab. 2. Udział procesów mrozowych w rozwoju brzegów rzecznych (\%)

Table 2. Share of frost phenomena in the evolution of riverbanks (\%)

\begin{tabular}{|c|c|c|c|c|c|c|}
\hline \multirow{3}{*}{$\begin{array}{c}\text { Stanowisko } \\
\text { Site }\end{array}$} & \multirow{2}{*}{$\begin{array}{c}\text { Poligon } \\
\text { Plot }\end{array}$} & \multicolumn{5}{|c|}{ Udział procesów mrozowych w sumarycznej erozji brzegu } \\
\cline { 3 - 7 } & & $\begin{array}{r}\text { rząd 1 [\%] } \\
\text { row 1 [\%] }\end{array}$ & $\begin{array}{c}\text { rząd 2 [\%] } \\
\text { row 2 [\%] }\end{array}$ & $\begin{array}{c}\text { rząd 3 [\%] } \\
\text { row 3 [\%] }\end{array}$ & $\begin{array}{c}\text { rzą 4 [\%] } \\
\text { row 4 [\%] }\end{array}$ & $\begin{array}{c}\text { średnia [\%] } \\
\text { mean [\%] }\end{array}$ \\
\hline \multirow{2}{*}{1} & A & $*$ & $*$ & $*$ & $*$ & $*$ \\
\cline { 2 - 7 } & B & 33,2 & 18,0 & 18,9 & & 22,6 \\
\hline \multirow{3}{*}{2} & A & $*$ & $*$ & $*$ & $*$ & $*$ \\
\cline { 2 - 7 } & B & $*$ & $*$ & $*$ & $*$ & $*$ \\
\cline { 2 - 7 } & C & 14,9 & 14,7 & 9,9 & & 13,0 \\
\hline 3 & A & 76,5 & $* *$ & 53,5 & & 50,6 \\
\hline 4 & A & $*$ & $*$ & $*$ & $*$ & $*$ \\
\hline 5 & A & 28,1 & 44,2 & 18,5 & & 31,8 \\
\hline
\end{tabular}

\section{Objaśnienia:}

* poligony zniszczone podczas wezbrania w maju 2014

** w okresie jesienno-zimowym notowano depozycję w płaszczyźnie kołków erozyjnych Określenie wielkości cofnięcia się brzegu ze względu na jego zasłonięcie materiałem osypiskowym jest niemożliwe do stwierdzenia.

\section{Explanations:}

* plot was destroyed during the flood in May 2014

** deposition was observed at the level of erosion pins during the fall-winter season The amount of bank retreat could not be determined because of the scree cover.

najwyższego rzędu kołków (2,0 m nad lustrem wody) została zerodowana o 3,8 cm, w strefie drugiego od góry $(1,5 \mathrm{~m})$ o $7,8 \mathrm{~cm}$. Wzdłuż dwóch najniższych rzędów $(1,0 \mathrm{~m}, 0,5 \mathrm{~m})$ notowano głównie pęcznienie gruntu oraz depozycję materiału osypiskowego, które powodowały pozorne pogrążenie kołków lub ich częściowe zasypanie (tab. 1). Materiał osypiskowy gromadzony na lodzie rzecznym był w okresach bez zlodzenia rzeki odprowadzany przez wodę od brzegu.

Brzeg ze stanowiskiem 5 ma zapis erozji w pełnym roku hydrologicznym. Wezbranie majowe w 2014 r. ominęło badany fragment brzegu, ponieważ nurt rzeki wyciął rynnę w innej części koryta, pozostawiając miejsce ze stanowiskiem badawczym w odciętym zakolu koryta. Wszystkie rzędy prętów pozostały od końca maja nad poziomem wody w powstałym starorzeczu. Na tym stanowisku w zimowych okresach multigelacji powierzchnia brzegu została zerodowana przez procesy mrozowe 
średnio o 7,7 cm. Większe ubytki tej powierzchni stwierdzono w górnym $(1,5 \mathrm{~m}$ nad lustrem wody) i środkowym $(1,0 \mathrm{~m})$ rzędzie prętów $(8,6-11,9 \mathrm{~cm})$, najmniejsze w dolnym $(0,5 \mathrm{~m})$ rzędzie $(2,9 \mathrm{~cm})$. Powierzchnia brzegu została bardziej zerodowana w okresie od wiosennych roztopów po wezbranie majowe przez płynącą wodę i procesy grawitacyjne - średnio o ok. 16,5 cm. Szczególnie duże ubytki brzegu zarejestrowano w najwyższej części brzegu. Długie nawisy darniowe wzdłuż górnej krawędzi brzegu, powstałe okresach multigelacji, uległy po deszczach oberwaniu lub zsunięciu się do nieczynnego już koryta Małego Rogoźnika.

\section{Dyskusja i wnioski}

Udział procesów mrozowych (wraz z subarealnymi i masowymi) w erozji stoków badanych brzegów był w ciągu roku hydrologicznego 2013/2014 zróżnicowany (tab. 1, ryc. 5). Na stanowisku 1 można było określić ten udział tylko na poligonie B, ponieważ poligon A zniszczyło majowe wezbranie i tym samym zabrakło danych do porównania z erozją fluwialną. Na poligonie B udział procesów mrozowych wynosił 22,6\% (od 33,2\% w górnej części brzegu, do 18,1\% w części środkowej stoku) (tab. 2). Na stanowisku 2 średni udział tych procesów, obliczony dla całego stoku, wyniósł na poligonie C tylko 13\% (pozostałe poligony zostały zniszczone). Także na tym brzegu większe ubytki stwierdzono w górnej części stoku. Na stanowisku 3 udział procesów mrozowych w erozji brzegu rzeki był większy od skutków erozji fluwialnej, zwłaszcza w górnej jego części (aż 75\% całorocznej erozji górnym rzędzie kołków) (ryc. 5). Na stanowisku 4, gdzie osady budujące brzeg były jednorodne, skutki erozji przez procesy mrozowe były niewielkie (tab. 2, ryc. 5), w dodatku niemożliwe do porównania z wielkością erozji fluwialnej (ponad $80 \mathrm{~cm}$ ), ponieważ stanowisko zostało zniszczone przez majowe wezbranie. Na ostatnim ze stanowisk badawczych (5) udział procesów mrozowych w sumarycznej erozji brzegu był bardzo różny na poszczególnych jego wysokościach (w rzędach kołków erozyjnych). W środkowej części brzegu wyniósł on 44,2\%, a w dolnej tylko 18,5\% (tab. 2).

Średni udział procesów mrozowych w erozji całej powierzchni czoła brzegu, na czterech zachowanych stanowiskach, wahał się od 13\% (stanowisko 2) do 50,6\% (stanowisko 3) (tab. 2, kol. 7). Wielkości te są procentowym udziałem takiej erozji (suma ze wszystkich rzędów kołków na danym poligonie - tab. 1) w sumarycznej/ rocznej erozji brzegu. Jej mały udział na stanowisku 2 (poligon C) wynikał z mniejszej podatności osadów na działanie procesów mrozowych (brzeg w całości żwirowy). Na stanowisku 3 jej procentowy udział był zdecydowanie większy, ponieważ erozja fluwialna była tam niewielka (mniejsze było wezbranie na potoku Molczy, w dodatku ilasty cokół terasy okazał się odporniejszy na erozję fluwialną niż żwiry i piaszczyste gliny). 
Porównując udziały procesów mrozowych (wraz z subarealnymi i masowymi) z fluwialnymi w sumarycznej erozji brzegów Wielkiego Rogoźnika i jego dopływów, można stwierdzić, że w roku hydrologicznym 2013/2014 aż 4-krotnie większy udział miała erozja fluwialna (79,7\%). Jest to w dużej mierze skutek majowego wezbrania rzeki, kiedy to poziom wody sięgał blisko górnej krawędzi brzegów. To wówczas intensywne procesy erozyjne i grawitacyjne najbardziej odsłoniły kołki erozyjne z powierzchni brzegów, a na 3 stanowiskach sięgnęły głębiej niż kołki, niszcząc $4 \mathrm{z}$ badawczych poligonów. Jest możliwe, że na tych poligonach udział procesów fluwialnych mógł być jeszcze większy (zmniejszając tym samym udział procesów mrozowych).

Procesy mrozowe (wraz z subarealnymi i masowymi) nierównomiernie erodowały stoki brzegów. W górnych częściach stoków, gdzie osady były słabiej skonsolidowane i bardziej drobnoziarniste, skutki erozji były znacznie większe niż w dolnych częściach stoków (z osadami grubszymi i silniej skonsolidowanymi) (ryc. 5). Na tej podstawie można wnioskować, że osady bardziej drobne i słabiej skonsolidowane są łatwiej erodowane w okresach multigelacji. Jest też możliwe, że wynika to z silniejszego zamarzania brzegu przy górnej krawędzi (dwukierunkowy front zamarzania, słabsza osłona śniegiem, bo większa stromość powierzchni) (Augustowski, Kukulak 2013). Wolniejsze cofanie się dolnych części stoków to również „zasługa” ich osłony przed erozją deponowanym w tym miejscu materiałem osypiskowym pochodzącym z górnych części brzegu. Jest to szczególnie widoczne w okresach zlodzenia rzek (stanowisko 3) lub w miejscach osłoniętych łachą przed nurtem rzek (stanowisko 4). Materiał ten podczas wezbrań zasila rzeki w rumowisko.

Podobny przebieg procesów mrozowych i ich skutki w niszczeniu brzegów udokumentował szczegółowo Teisseyre (1984) na rzekach sudeckich. Autor ten podkreśla również dużą rolę zjawisk lodowych w erozji brzegów (w poziomie rzeki) oraz znaczenie erozji fluwialnej, związanej z odwilżami i roztopami, ale preferowanej przede wszystkim „destrukcyjnym działaniem lodu gruntowego na strukturę i wytrzymałość wszystkich gruntów aluwialnych, a zwłaszcza kohezyjnych” (Teisseyre 1979). Także Rachocki (1974) - na przykładzie brzegów Raduni, oraz Kalinowski i in. (2012) - na przykładzie brzegów Łyny, zwracają uwagę, że zimą najniższe części brzegów mogą być erodowane przez zjawiska lodowe (lód brzegowy, pokrywę lodowa, spływ kry lodowej). Dolne części brzegów Wielkiego Rogoźnika są jednak wycięte w skonsolidowanych żwirach lub twardoplastycznych iłach neogeńskich, a nie w mułkach i piaskach, jak Radunia i Łyna, dlatego wielkość erozji wywołana zjawiskami lodowymi jest na Podhalu mniejsza, jakkolwiek zapewne występuje. W publikacjach o erozji brzegów przez procesy mrozowe zwraca się uwagę także na egzarację (erozję lodową), która przez termiczne i dynamiczne oddziaływanie pokrywy lodowej niszczy brzegi zbiorników zaporowych (Banach 1988; Gierszewski 1988). Strefą erozji jest pas brzegów objętych wahaniami lustra wody z pokrywą 
lodową. W korycie Wielkiego Rogoźnika zimą 2013/2014 wahania poziomu rzeki były niewielkie (ryc. 4), a zwarta pokrywa lodowa utrzymywała się dwukrotnie przy podobnym poziomie rzeki, dlatego ten rodzaj erozji praktycznie nie miał znaczenia.

Inaczej na czołach brzegów zaznacza się skuteczność erozji fluwialnej (ryc. 5). Największe ubytki tej powierzchni są w jej częściach dolnych. Cofanie się czoła brzegu w półroczu letnim postępuje szybciej przy jego podstawie. Podcinanie brzegów przez płynącą wodę uruchamia zwykle ruchy masowe na brzegach, ale materiał obrywowy jest systematycznie usuwany w dół koryta. Ten rodzaj erozji postępuje tylko w okresach podwyższonych stanów wody w rzece (do kilku razy w półroczu letnim), jakkolwiek efekty erozji mogą wielokrotnie przewyższać skuteczność procesów mrozowych. Świadczą o tym m.in. opisy stabilności brzegów rzek karpackich i sudeckich podczas wezbrań (np. Teisseyre 1984; Gorczyca 2004; Starkel 2006).

Określenie wielkości udziału procesów mrozowych w erozji brzegów rzecznych wymaga dalszych badań. Potrzebne są szczegółowe pomiary erozji prowadzone na poligonach uwzględniających możliwie wszystkie warunki miejsc badanych, dotyczących zarówno podłoża brzegów, jak i cech zewnętrznych (m.in. stopień i długotrwałość osłony stoku przez pokrywę śnieżną, siłę i kierunki wiatru, stały monitoring położenia frontu zamarzania w gruncie, czas trwania dodatniej temperatury w przypowierzchniowej części stoku w całym okresie multigelacji, ekspozycja stoku na brzegach łukowych). Porównanie wielkości erozji brzegów przez procesy fluwialne i mrozowe (razem z subarealnymi i masowymi) w ujęciu wieloletnim będzie możliwe tylko na stokach czynnych w tym okresie, a narzędziem badawczym, stosownym dla tego typu badań, jak się wydaje, jest naziemny skaning laserowy (LiDAR).

\section{Literatura}

Abernethy B., Rutherfurd I.D., 1998, Where along a river's length will vegetation most effectively stabilise stream banks?, Geomorphology, 23, 55-75.

Arens S.M., Slings Q., de Vries C.N., 2004, Mobility of a remobilised parabolic dune in Kennemerland, The Netherlands, Geomorphology, 59, 175-188.

Augustowski K., 2012, The role of multigelation in the development of river banks, Georeviv, 22 (1), 56-66.

Augustowski K., 2013, Niszcenie brะegów ræecznych præez procesy mrozowe na przyktadach dorzecza Dunajca i Ropy w 2011 i 2012 roku, Czasopismo Geograficzne, 83 (3-4), 157-174.

Augustowski K., Chmielowska D., Kukulak J., Zawiejska J., 2012, Varied riverbank stability in the voreland of the Tatra Mountains, Geomorhologia Slovaca et Bohemica, 1, 23-31.

Augustowski K., Chmielowska D., Kukulak J., 2013, Geologicæne wwarunkowania dynamiki procesow bræegowych ræek sachodniego Podhala, Przegląd Geologiczny, 6 (12), 755-763.

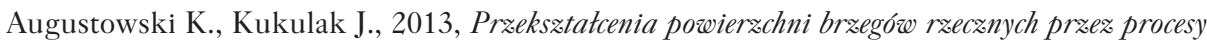
mrozowe, Landform Analysis, 24, 3-10. 
Banach M., 1988, Gtówne procesy a osady w strefie bræegowej sbiornika Wtoctawek, Przegląd Geograficzny, 60 (3), 267-299.

Banach M., Grobelska H., 2003, Stan dynamiki bræegów zbiornika Jeziorsko, Słupskie Prace Geograficzne, 1, 91-106.

Bartley R., Keen R.J., Hawdon A.A., Disher M.G., Kinsey-Henderson A.E., Hairsine P.B., 2006, Measuring rates of bank erosion and channel change in northern Australia: A case study from the Daintree River catchment, Reef and Rainforest CRC Final Report, CSIRO Land and Water Science Report 43/06, 51, http://www.clw.csiro.au/publications/science/2006/ sr43-06.pdf (13.06.2015).

Bertrand F., 2010, Fluvial erosion measurements of streambank using Photo-Electronic Erosion Pins (PEEP), Ph.D. Thesis, University of Iowa, http://ir.uiowa.edu/cgi/viewcontent.cgi?article $=1827 \&$ context=etd $(10.02 .2013)$.

Coffman D., 2009, Streambank Erosion Assessment in Non-cohesive Channels Using Erosion Pins and Submerged Jet Testing, Dallas/Fort Worth, Texas, Ph.D. Thesis, http://beardocs.baylor.edu/ xmlui/bitstream/handle/2104/5318/David_Coffman_Masters.pdf?sequence=1 (12.04.2012).

Couper P., 2003, Effects of silt-clay content on the susceptibility of river banks to subaerial erosion, Geomorphology, 56, 95-108.

Couper P.R., Maddock I.P., 2001, Subaerial river bank erosion processes and their interaction with other bank erosion mechanisms on the River Arrow, Warwickshire, UK, Earth Surface Processes and Landforms, 26, 631-646.

Dutkiewicz L., 1967, The distribution of periglacial phenomena In NW-Sörkapp, Spitsbergen, Biuletyn Peryglacjalny, 16, 37-83.

Gierszewski P., 1988, Zmiany br«egów wywołane termicะnymi ruchami lodu na przykładzie zbiornika włocławskiego, Przegląd Geologiczny, 60 (4), 657-674.

Gorczyca E., 2004, Przeksztatcanie stoków fliszowych przez procesy masowe podczas katastrofalnych opadów (doræecze Łososiny), Wydawnictwo Uniwersytetu Jagiellońskiego, Kraków.

Green T.R., Beavis S.G., Dietrich C.R., Jakeman A.J., 1999, Relating stream-bank erosion to in-stream transport of suspended sediment, Hydrological Processes, 13, 777-787.

Hill A.R., 1973, Erosion of river banks composed of glacial till near Belfast, Northern Ireland, Zeitschrift für Geomorphologie, 17 (4), 428-442.

Hooke J.M., 1979, An analysis of the processes of river bank erosion, Journal of Hydrology, 42, 39-62.

Howard A., Raine S.R., Titmarsh G., 1998, The Contribution of Stream Bank Erosion to Sediment Loads in Gowrie Creek, Toowoomba, University of Southern Quennsland, Australia, http:// www.usq.edu.au/users/raine/index_files/ASSSI98_Howard_etal.pdf (10.04.2012).

Hupp C.R., Schenk E.R., Richter J.M., Peet R.K., Townsend P.A., 2009, Bank erosion along the dam-regulated lower Roanoke River. North Carolina, The Geological Society of America, Special Paper, 451.

Jahn A., 1961, Quantitative Analysis of some Periglacial Processess In Spitsbergen, Zeszyty Naukowe Uniwersytetu Wrocławskiego, ser. B, 5, 1857-1959. 
Kalinowski A., Glińska-Lewczuk K., Burandt P., Banaszek Ż., 2012, Wpływ zjawisk lodowych na erozje brzegów koryta rzecznego na przyktadzie Łyny, Inżynieria Ekologiczna, 31, 57-71.

Kronvang B., Audet J., Baattrup-Pedersen A., Jensen H.S., Larsen S.E., 2012, Phosphorus Load to Surface Water from Bank Erosion in a Danish Lowland River Basin, Journal of Environmental Quality, 41, 304-313.

Lawler D.M., 1992, Process dominance in bank erosion systems, [w:] P. Carling, G.E. Petts (red.), Lowland Floodplain Rivers, John Wiley \& Sons, New York, 117-143.

Lawler D.M., 1993, Needle ice processes and sediment mobilisation on river bends; the River Ilston, West Glamorgan, UK, Journal of Hydrology, 150, 81-114.

Lawler D.M., 1995, The impact of scale on the processes of channelside sediment supply: A conceptual model, [w:] W.T. Osterkamp (red.), Effects of Scale on Interpretation and Management of Sediment and Water Quality, IAHS Pub., vol. 226. IAHS Press, Wallingford, UK, 175-184.

Lawler D.M., Thorne C.R., Hooke J.M., 1997, Bank erosion and instability, [w:] C.R. Thorne, R.D. Hey, M.D. Newson (red.), Applied Fluvial Geomorphology for River Engineering and Management, Wiley, Chichester, 137-172.

Lawler D.M., Grove J.R., Couperthwaite J.S., Leeks G.J.L., 1999, Downstream change in river bank erosion rates in the Swale-Ouse system, northern England, Hydrological Processes, 13, 977-992.

Luppi L., Rinaldi M., Teruggi L.B., Darby S.E., Nardi L., 2008, Monitoring and numerical modelling of riverbank erosion processes: A case study along the Cecina River (central Italy), Earth Surface Processes and Landforms, 34 (4), 530-546.

Mengoni B., Mosselman E., 2006, Analysis of riverbank erosion processes: Cecina river, Italy, [w:] G. Parker, M.H. García (red.), River, Coastal and Estuarine Morphodynamics: RCEM 2005, Taylor \& Francis Group, London, 943-951.

Merritt D.M., Cooper D.J., 2000, Riparian vegetation and channel change in response to river regulation: A comparative study of regulated and unregulated streams in the Green River Basin, USA, Regulated Rivers: Research and Management, 16, 543-564.

Neill G.R., Yaremko E.K., 1989, Identifying causes and predicting effects of bank erosion, National Conf. Hydraulic Eng., 14-18 August, New Orleans, Louisiana.

Pilarczyk K.W., Havinga H., Klaasen G.J., Verhey H.J., Mosselman E., Leemans J.A., 1989, Control of bank erosion in the Netherlands, State-of-the-art. Conf. Hydr. Eng. ASCE New Orleans, 1-32.

Przedwojski B., 1998, Morfologia rzek i prognozowanie procesów ræecznych, Wydawnictwo Akademii Rolniczej im. Augusta Cieszkowskiego, Poznań.

Rachocki A., 1974, Przebieg i natę̇̇enie wespótczesnych procesów ræecznych w korycie Raduni, Dokumentacja Geograficzna, 4, 1-117.

Reid J.R., 1985, Bank-erosion processes in a cool-temperate environment, Orwell Lake, Minnesota, Geological Society of America Bulletin, 96 (6), 781-792.

Reid J.R., 1992, Bank recession causes, measurement techniques, rates and predictions, Lake Sakakawea, North Dakota, Missouri River Division Sediment Ser. 38, Omaha, Nebraska. 
Reid J.R., Sandberg B.S., Millsop M.D., 1988, Bank recession processes, rates and prediction, Lake Sakakawea, North Dakota, U.S.A, Geomorphology, 1, 161-189.

Rocznik Meteorologic ny 1963, PIHM.

Saynor M.J., Erskine W.D., Evans K.G., 2003, Bank erosion in the Ngarradj catchment: Results of erosion pin measurements between 1998 and 2001, Supervising Scientist Report 176, Supervising Scientist, Darwin NT, 40.

Shi Z., Wen A., Zhang X., Yan D., 2011, Comparison of the soil losses from 7Be measurements and the monitoring data by erosion pins and runoff plots in the Three Gorges Reservoir region, China, Applied Radiation and Isotopes, 69, 1343-1348.

Simon A., Hupp C.R., 1992, Geomorphic and Vegetative Recovery Processes along Modified Stream Channels of West Tennessee, U.S, Geological Survey Open-File Report 91-502, 142.

Simon A., Rinaldi M., 2000, Channel instability in the loess area of the Midwestern United States, Journal of the American Water Resources Association, 36, 133-150.

Sirvent J., Desir G., Gutierrez M., Sancho C., Benito G., 1997, Erosion rates in badland areas recorded by collectors, erosion pins and profilometer techniques (Ebro Basin, NE-Spain), Geomorphology, 18, 61-75.

Starkel L., 2006, Geomorphic hazards in the Polish Flysch Carpathians, Studia Geomorphologica Carpatho-Balcanica, 40, 7-19.

Teisseyre A.K., 1979, Præebieg wjawisk fluwialnych w simie na przyktadzie matych ræek sudeckich, Geologica Sudetica, 14 (1), 1-54.

Teisseyre A.K., 1984, Procesy fluwialne i rowwój koryta górnego Bobru na odcinku badawczym w Btazkowej (1967-1982), Geologica Sudetica, 19 (1), 7-71.

Thorne C.R., 1982, Processes and mechanisms of river bank erosion, [w:] R.D. Hey, J.C. Bathurst, C.R. Thorne (red.), Gravel-Bed Rivers, Wiley, Chichester, 227-272.

Thorne C.R., 1990, Effects of vegetation on river bank erosion and stability, [w:] J.B. Thornes (red.), Vegetation and Erosion, Wiley, Chichester, 125-144.

Thorne C.R., Lewin J., 1979, Bank processes, bed material movement and planform development in a meandering river, [w:] D.D. Rhodes, G.P. Williams (red.), Adjustments of the Fluvial System, Allen and Unwin, London, 117-137.

Vallejo L.E., 1977, Mechanics of the stability and development of the Great Lakes coastal bluffs, Ph.D. dissertation, University of Wisconsin-Madison, Madison, Wisconsin.

Vallejo L.E., 1990, Bluff retreat by frost action in the Great Lakes, [w:] $33^{\text {rd }}$ Annual Meeting Technical Program Abstracts, Association of Engineering Geologists, 1-5 October, Pittsburgh, Pennsylvania, 50-51.

Van Klaveren R.W., McCool D.K., 1998, Erodibility and critical shear of a previously frozen soil, Transactions of the Asae, 41 (5), 1315-1321.

Wolman M.G., 1959, Factors influencing erosion of a cohesive river bank, American Journal of Science 257, 204-216.

Wynn T.M., Mostaghimi S., 2006, The effects of vegetation and soil type on streambank erosion, Southwestern Virginia, USA, Journal of the American Water Resources Association, 42, 69-82. 
Wynn T.M., Henderson M.B., Vaughan D.H., 2008, Changes in streambank erodibility and critical shear stress due to subaerial processes along a headwater stream, southwestern Virginia, USA, Geomorphology, 97, 260-273.

Yumoto M., Ogata T., Matsuoka N., Matsumoto E., 2006, Riverbank freeze-thaw erosion along a small mountain stream, NikkoVolcanic Area, Central Japan, Permafrost and Periglacial Processes, 17, 325-339.

Karol Augustowski

Uniwersytet Pedagogiczny im. KEN w Krakowie ul. Podchorązych 2, 30-084 Kraków

karolaug@up.krakow.pl

Jóef Kukulak

Uniwersytet Pedagogicwny im. KEN w Krakowie ul. Podchorqżych 2, 30-084 Kraków

jkukulak@up.krakow.pl 
